\title{
Effect of stocking density and probiotic dietary supplementation on growth performance, feed conversion and survival of postlarvae of the freshwater prawn (Macrobrachium rosenbergii)
}

\author{
Nabil F. Abdel-Hakim; Al-Desoki A. Al-Azab; Hasan Y. Allam and
}

Ahmed G. A. Gewida.

Department of Animal production, Faculty of Agriculture, Al-Azhar University, Cairo, Egypt.

\section{ABSTRACT}

The present study was conducted at the Fish Hatchery Saft Khalid, Behera Governorate, Egypt, for two months in order to investigate the effect of stocking density and probiotic (Ecobiol Aqua) dietary supplementation on growth performance, feed utilization, survival rate and whole body chemical composition of postlarvae of the freshwater prawn (Macrobrachium rosenbergii) of an initial weight $0.161 \mathrm{~g}$. reared in indoor nursery concrete tanks. A total number of 1350 postlarvae freshwater prawns were divided randomly into 18 concrete tanks $\left(1 \mathrm{~m}^{2}\right.$ area each) to represent three stocking densities $\left(50 ; 75\right.$ and $\left.100 \mathrm{PL} / \mathrm{m}^{2}\right)$ with or without probiotic supplementation in three replicates each treatment. The experimental prawns were fed during the experimental period ( 8 weeks) on a diet contained $37.5 \%$ crude protein 5times/day at a rate related to the development stage. The treatments applied were $\mathrm{D}_{1} \mathrm{~A} ; \mathrm{D}_{2} \mathrm{~A} ; \mathrm{D}_{3} \mathrm{~A} ; \mathrm{D}_{1} \mathrm{~B} ; \mathrm{D}_{2} \mathrm{~B}$ and $\mathrm{D}_{3} \mathrm{~B}$ i.e. densities $50 ; 75$ and 100 animals $/ \mathrm{m}^{2}$ without probiotic and densities 50;75 and 100 animals $/ \mathrm{m}^{2}$ with supplemental probiotics, respectively. Results obtained are summarized in the following:

1- Water quality parameters tested were within the permissible levels recommended for optimum growth and development of freshwater prawn.

2- Both densities $\mathrm{D}_{1}$ and $\mathrm{D}_{2}$ (50 and 75 animals $\left./ \mathrm{m}^{2}\right)$ recorded significantly $(p<0.05)$ higher final weights; total weight gains; specific and relative growth rates compared to the highest density, regardless of the probiotic effect.

3- Probiotic supplementation had insignificant effects on final weight; total weight gain; specific and relative growth rates, regardless of stocking density.

4- Within each stocking density supplementing the diets of freshwater prawn with probiotic improved the survival rate and the improvements were more pronounced at the lower stocking densities.

5- The best feed conversion ratio (FCR) (the lowest) was recorded by $\mathrm{D}_{1} \mathrm{~A}$ group $(p<0.05)$ followed by $\mathrm{D}_{2} \mathrm{~B} ; \mathrm{D}_{1} \mathrm{~B} ; \mathrm{D}_{2} \mathrm{~A} ; \mathrm{D}_{3} \mathrm{~B}$ and $\mathrm{D}_{3} \mathrm{~A}$, respectively.

6- Neither stocking density nor probiotic supplementation released any significant effects on whole body chemical composition of freshwater prawn.

Based on the obtained results, the optimum stocking density of postlarvae $M$. rosenbergii laid between 50 to 75 animals $/ \mathrm{m}^{2}$ and increasing the stocking density more than $75 / \mathrm{m}^{2}$ had negative effects on growth performance parameters. Also the results obtained may lead us to recommend the supplementation of probiotic (Ecobiol Aqua) to postlarvae $M$. rosenbergii diets in order to improve the survival rate during the nursery period.

Key words: Freshwater prawn, stocking density, probiotic. 


\section{INTRODUCTION}

Macrobrachium rosenbergii, the giant freshwater prawn is known to be the most important commercial prawn species in temperate climates. In Egypt the culture of such prawn has great economic interest due to the availability of wide brackish water surfaces, the suitability of the climatic conditions and the high market prices.

In Egypt, many farmers are devoted to freshwater prawn monoculture; however others practice polyculture of prawn with other fish species. Prawns have been successfully cultured with tilapia (Rouse et al., 1980), channel catfish (Huner et al., 1981) and Chinese carp (Malecha et al., 1981). The world production of freshwater prawn $(M$. rosenbergii) increased from $<50.000$ MT (metric tons) in 1995 to more than 280.000 MT in 2003 as reported by $\mathrm{FAO}(2005)$ and has become an important part of rice-fish or small scale carp polyculture system in many developing countries (Giap et al., 2005).

In view of $M$. rosenbergii faster growth rate, excellent demand in internal as well as export markets and higher prices, it is commanding in recent years, a growing interest has been noticed in farming of this species in Egypt and worldwide. Two of the main difficulties for communal culture of this species are cannibalism and social suppression of growth (Karplus et al., 1987). According to New et al. (2000), high stocking densities of prawns are less profitable due to the agonistic behavior of male prawns, this results in low stocking densities and less environmental impacts.

Development of bacterial resistance to antibiotics has been well documented and the fear of the spread of this resistance to human pathogens (Amabile-Cuevas et al., 1995) has recently led to the banning of several antibiotics as so-called growth promoters in animal husbandry within the European Union. This concern has also been raised in the aquaculture industry and has led to suggestions for other disease control measures, including the use of live nonpathogenic bacteria as probiotics (Westerdahl et al., 1991; Smith and Davey, 1993; Gatesoupe, 1994; Austin et al., 1995; Bly et al., 1997; Graam et al., 1999).

The main objective of the present study is to high light the optimal space requirement, the optimal stocking density as well as the effects of supplementing the diet of post larval stages of $M$. rosenbergii with probiotic (Ecobiol Aqua which contains spores of a strain of Bacillus amyloliquefaciens) on growth and survival during nursery period under Egyptian conditions.

\section{MATERIALS AND METHODS}

The present study was carried out at the Fish Hatchery in Saft-Khalid Behera Governorate. A total number of 1350 postlarvae of the freshwater prawn (Macrobrachium rosenbergii) of an initial weight $0.161 \mathrm{~g}$ were divided randomly into 6 experimental groups, representing three stocking densities $\left(50 ; 75\right.$ and $\left.100 \mathrm{PL} / \mathrm{m}^{2}\right)$ each fed on a diet without probiotic and with the tested probiotic (Ecobiol-aqua which contains spores of a strain of Bacillus amyloliquefaciens) supplemented to the diet at $0.01 \%$ level.

The treatments were applied in 18 concrete tanks divided with fine mesh nets to $1 \mathrm{~m}^{2}$ area, where the experimental prawns were stocked. The tanks were supplied with ground fresh water and to a depth of $50 \mathrm{~cm}$. level during the whole experimental period that lasted 8 weeks after start.

The prawn postlarvae were fed on commercial diet containing $37.5 \%$ crude protein and $4180 \mathrm{k}$ cal gross energy/kg diet with or without the tested probiotic. The 
diet was fed at $30 ; 20 ; 15 ; 12 ; 10 ; 10 ; 10$; and $7 \%$ rates of biomass in 5 equal portions daily. The treatments applied were $\mathrm{D}_{1} \mathrm{~A} ; \mathrm{D}_{2} \mathrm{~A} ; \mathrm{D}_{3} \mathrm{~A} ; \mathrm{D}_{1} \mathrm{~B} ; \mathrm{D}_{2} \mathrm{~B}$ and $\mathrm{D}_{3} \mathrm{~B}$ i.e. densities 50; 75 and 100 animal $/ \mathrm{m}^{2}$ without probiotic and densities 50;75 and 100 animal $/ \mathrm{m}^{2}$ with supplemental probiotics, respectively. The experimental tanks were supplied with aeration through an air blower for 24 hours.

\section{Physicochemical analysis of experimental tanks water:}

Water quality parameters were adjusted every two weeks during the experimental period. Water temperature $\left({ }^{\circ} \mathrm{c}\right)$ in the experimental ponds was measured two times daily (at $6 \mathrm{am}$. and $6 \mathrm{O}^{\prime}$ clock pm.), dissolved oxygen (DO) (mg/l) was measured two times daily (at 6 am. and 6 O'clock pm.) using oxygen thermometer apparatus (YSI model 58, Yellow Spring Instrument, Ohio, USA.), water $\mathrm{pH}$ was measured by using a pH meter (Digital Mini-pH Meter, model 55, Fisher Scientific, Denver, USA), water turbidity NTU (nephlometric turbidity unit) was measured by using a Turbidity meter model HACH $2100 \mathrm{~N}$., total ammonia (mg/l) and nitrite $(\mathrm{mg} / \mathrm{l})$ ware determined by using a spectrophotometer model Cecil 3021 series 3000 according to APHA (1992) and total dissolved salts (TDS) (mg/l) was determined using a conductivity meter $(\mathrm{m} \mathrm{sec} / \mathrm{cm})$ model Orion star 3 and the factor 0.67 was used to calculate the TDS from the reading of the conductivity meter.

\section{Analytical methods:}

The proximate chemical analysis of diet and prawn were carried out according to the methods described by A.O.A.C. (1990) for moisture, crude protein (CP), ether extract(EE), crud fiber (CF) and total ash contents (Table 1) while nitrogen free extract (NFE) was calculated by difference. Gross energy contents of the commercial diet used were calculated from their chemical composition, using the factors 5.64, 9.44, 4.00 and $4.00(\mathrm{k} \mathrm{cal} / \mathrm{g}$ ) for protein, fat, fiber and NFE, respectively (Jobling, 1983).

Table 1: The proximate analysis of experimental diet.

\begin{tabular}{|l|c|c|c|c|c|}
\hline & Moisture & Ash & CF & CP & EE \\
\hline Fish meal & 9.48 & 26.69 & 5.75 & 60.08 & 1.88 \\
\hline Shrimp meal & 6.13 & 52.51 & 2.60 & 23.26 & 3.96 \\
\hline Soybean meal & 13.61 & 7.19 & 2.34 & 39.21 & 4.90 \\
\hline Corn gluten meal & 10.95 & 2.51 & 0.84 & 63.17 & 0.96 \\
\hline Rice bran & 14.92 & 4.42 & 3.77 & 13.69 & 0.62 \\
\hline Diet * & 7.70 & 22.62 & 8.55 & 37.50 & 2.10 \\
\hline
\end{tabular}

*NFE contents of the diet was calculated by differences

$$
\begin{aligned}
\mathbf{N F E} & =100-(\mathrm{CP}+\mathrm{Ash}+\mathrm{EE}+\mathrm{CF}) \\
& =100-(37.5+22.62+8.55+2.10) \\
& =100-70.77=29.23
\end{aligned}
$$

Gross Energy $=$ C.P. $* 85.65+$ E.E. $* 9.45+$ C.F. $* 4.00+$ N.F.E. $* 4.00$

$$
\begin{aligned}
& =(37.5 * 85.65)+(8.55 * 9.45)+(2.10 * 4.00)+(29.23 * 4.00) \\
& =211.88+80.80+8.40+116.92 \\
& =418 * 10=4180 \mathrm{k} \mathrm{Cal} / \mathrm{kg} \text { diet According to (Jobling, } 1983)
\end{aligned}
$$

\section{Growth performance parameters:}

Bodyweight: was measured every week in a sample of 30 postlarvae to adjust the feeding

rate for the following period.

The following growth performance parameters were recorded:

Total weight gain $($ TWG) $=\mathrm{W} 1-\mathrm{W} 0$

Specific growth rate $($ SGR) $(\% /$ day $)=(\mathrm{Ln} . \mathrm{W} 1-\mathrm{Ln} . \mathrm{W} 0) / \mathrm{T} * 100$ 
Average daily gain $($ ADG $)(\mathrm{g} /$ day $)=(\mathrm{W} 1-\mathrm{W} 0) / \mathrm{T}$

Relative growth rate $(\mathbf{R G R})(\%)=(\mathrm{TWG} / \mathrm{W} 0) * 100$

Where:W0 Initial body weight $(\mathrm{g})$

W1 Final body weight (g)

Ln Natural logarithm

$\mathrm{T} \quad$ Experimental period (days)

Feed Intake (FI) $(\mathrm{g})=\quad$ Total feed offered $(\mathrm{g})$

(Initial number of prawns + final number of prawns) $/ 2$

Feed conversion ratio $($ FCR $)(\mathrm{g})=$ Feed intake $(\mathrm{g}) /$ Weight gain $(\mathrm{g})$

Survival rate (SR) $(\%)=\underline{\text { Number of prawns survived at the end of the experiment }} * 100$

Statistical analysis:

Number of prawns stocked at the start of the experiment

Data of the present study were statistically evaluated using the SAS version 9 (SAS Institute, 2002) statistical package. Data were statistically analyzed in a Factorial design procedure according to Snedecor and Coahran (1982). Means of treatments were compared by Duncan (1955) multiple range test. Duncan test $(\mathrm{p}<0.05)$ was used to compare means and $(\mathrm{F}<0.05)$ was considered for the variance analyses.

\section{RESULTS AND DISCUSSION}

Results presented in Table (2) show that average water quality parameters during the experimental period including water temperature $\left({ }^{\circ} \mathrm{c}\right) ; \mathrm{pH}$; turbidity (NTU); total ammonia (mg/l); nitrite $(\mathrm{mg} / \mathrm{l})$; dissolved Oxygen $(\mathrm{mg} / \mathrm{l})$ and total dissolved salts $(\mathrm{mg} / \mathrm{l})$ were within the permissible ranges for growth and development of $M$. rosenbergii postlarvae. They agree with the ranges suggested by Armstrong et al. (1976); Hsieh et al. (1990); New (1990) and Saxena (2003).

Table 2: Ranges of water quality parameters during the experimental period.

\begin{tabular}{|c|c|c|c|}
\hline Treatments & $D_{1}(A, B)$ & $\mathbf{D}_{2}(\mathbf{A}, \mathbf{B})$ & $\mathbf{D}_{3}(\mathbf{A}, \mathbf{B})$ \\
\hline Temperature $\left({ }^{\circ} \mathrm{C}\right)$ & $27-29$ & $27-29$ & $27-29$ \\
\hline pH & $7.9-8.2$ & $7.7-8.0$ & $7.5-7.8$ \\
\hline Turbidity (NTU) & $0.4-0.6$ & $1.1-1.3$ & $1.8-2.0$ \\
\hline Total ammonia (mg/l) & $0.02-0.08$ & $0.06-0.10$ & $0.10-0.12$ \\
\hline Nitrite $(\mathrm{mg} / \mathrm{l})$ & $0.02-0.04$ & $0.03-0.05$ & $0.03-0.05$ \\
\hline Dissolved Oxygen (mg/l) & $4.5-5.5$ & $4.5-5.5$ & $4.5-5.5$ \\
\hline Total dissolved salinity (mg/l) & $705-715$ & $705-715$ & $755-715$ \\
\hline \multicolumn{4}{|l|}{ Where: } \\
\hline $\mathrm{D}_{1} \rightarrow 50 \mathrm{pl} / \mathrm{m}^{2}$ & & \multicolumn{2}{|c|}{ (A) $\rightarrow$ without probiotic } \\
\hline $\mathrm{D}_{2} \rightarrow 75 \mathrm{pl} / \mathrm{m}^{2}$ & & \multicolumn{2}{|c|}{ (B) $\rightarrow$ with probiotic } \\
\hline $\mathrm{D}_{3} \rightarrow 100 \mathrm{pl} / \mathrm{m}^{2}$ & & & \\
\hline
\end{tabular}

\section{Growth performance parameters:}

As presented in Table (3), group $\mathrm{D}_{1} \mathrm{~A}$ recorded significantly $(\mathrm{P}<0.05)$ the highest final weight (FW); total weight gain (TWG); average daily gain (ADG); specific growth rate (SGR) and relative growth rate (RGR) compared to $\mathrm{D}_{1} \mathrm{~B} ; \mathrm{D}_{3} \mathrm{~A}$ and $\mathrm{D}_{3} \mathrm{~B}$ groups, however differences among $\mathrm{D}_{1} \mathrm{~A} ; \mathrm{D}_{2} \mathrm{~A}$ and $\mathrm{D}_{2} \mathrm{~B}$ groups in the growth traits cited above were insignificant $(\mathrm{P}>0.05)$. Also differences in growth performance parameters among $\mathrm{D}_{1} \mathrm{~B} ; \mathrm{D}_{3} \mathrm{~A}$ and $\mathrm{D}_{3} \mathrm{~B}$ groups were insignificant $(\mathrm{P}>0.05)$. Concerning survival rate (SR), results in Table (3) show that groups $D_{1} A ; D_{1} B ; D_{2} A$ and $\mathrm{D}_{3} \mathrm{~B}$ had significantly $(\mathrm{p}<0.05)$ higher survival rate compared to $\mathrm{D}_{3} \mathrm{~A}$ and $\mathrm{D}_{3} \mathrm{~B}$ groups however differences among $\mathrm{D}_{1} \mathrm{~A} ; \mathrm{D}_{1} \mathrm{~B} ; \mathrm{D}_{2} \mathrm{~A}$ and $\mathrm{D}_{2} \mathrm{~B}$ groups were 
insignificant ( $\mathrm{P}>0.05)$. In general, results in Table (3) indicate (except the group $\mathrm{D}_{1} \mathrm{~B}$ ) that supplementing freshwater prawn with the tested probiotic improved growth parameters within each stocking density tested.

As presented in the same Table, results revealed that regardless of probiotic effect, increasing the prawns stocking density from 50 to 75 animal $/ \mathrm{m}^{2}$ resulted in insignificant $(\mathrm{P}>0.05)$ differences in FW; TWG; ADG; SGR; RGR and SR, however increasing the stocking density to 100 animal $/ \mathrm{m}^{2}$ decreased all tested growth parameters and survival rate significantly $(\mathrm{P}<0.05)$. These results are in accordance with the findings of Phuong et al. (2003), Bays and Wahngchai (2007), El-Sherif and Ali Mervat (2009) and Langer et al. (2011).

Table 3: Growth performance parameters of $M$. rosenbergii as affected with stocking density and probiotic.

\begin{tabular}{|c|c|c|c|c|c|c|c|}
\hline & IW (g) & FW (g) & TWG (g) & $\begin{array}{c}\text { ADG } \\
\text { (g/prawn/day) }\end{array}$ & SGR (\%) & RGR (\%) & SR (\%) \\
\hline \multicolumn{8}{|c|}{ Interaction: } \\
\hline $\mathbf{D}_{1}(\mathbf{A})$ & $\begin{array}{c}0.161 \\
\pm \\
0.00\end{array}$ & $\begin{array}{c}1.216 \\
\pm \\
0.37^{\text {a }}\end{array}$ & $\begin{array}{c}1.056 \\
\pm \\
0.04^{\mathrm{a}}\end{array}$ & $\begin{array}{c}0.019 \\
\pm \\
0.00^{\mathrm{a}}\end{array}$ & $\begin{array}{c}3.610 \\
\pm \\
0.53^{\text {a }}\end{array}$ & $\begin{array}{c}655.69 \\
\pm \\
22.70^{\mathrm{a}}\end{array}$ & $\begin{array}{c}72.67 \\
\pm \\
3.33^{\mathrm{a}}\end{array}$ \\
\hline $\mathbf{D}_{1}(\mathbf{B})$ & $\begin{array}{c}0.161 \\
\pm \\
0.00 \\
\end{array}$ & $\begin{array}{c}0.847 \\
\pm \\
0.24 \mathrm{bc}\end{array}$ & $\begin{array}{c}0.686 \\
\pm \\
0.02^{\mathrm{bc}}\end{array}$ & $\begin{array}{c}0.012 \\
\pm \\
0.00^{\mathrm{bc}}\end{array}$ & $\begin{array}{c}2.964 \\
\pm \\
0.50^{\mathrm{bc}} \\
\end{array}$ & $\begin{array}{c}426.29 \\
\pm \\
14.73^{\text {bc }} \\
\end{array}$ & $\begin{array}{c}82.67 \\
\pm \\
2.40^{\mathrm{a}} \\
\end{array}$ \\
\hline $\mathbf{D}_{2}(\mathbf{A})$ & $\begin{array}{c}0.161 \\
\pm \\
0.00\end{array}$ & $\begin{array}{c}1.065 \\
\pm \\
0.16^{\text {ab }} \\
\end{array}$ & $\begin{array}{c}0.904 \\
\pm \\
0.16^{\mathrm{ab}}\end{array}$ & $\begin{array}{c}0.016 \\
\pm \\
0.00^{\mathrm{ab}}\end{array}$ & $\begin{array}{c}3.337 \\
\pm \\
0.26^{\mathrm{ab}}\end{array}$ & $\begin{array}{c}561.70 \\
\pm \\
96.33^{\text {ab }}\end{array}$ & $\begin{array}{c}74.00 \\
\pm \\
6.51^{\mathrm{a}}\end{array}$ \\
\hline $\mathbf{D}_{2}(\mathbf{B})$ & $\begin{array}{c}0.161 \\
\pm \\
0.00\end{array}$ & $\begin{array}{c}1.093 \\
\pm \\
0.08^{\mathrm{ab}}\end{array}$ & $\begin{array}{c}0.932 \\
\pm \\
0.08^{\mathrm{ab}}\end{array}$ & $\begin{array}{c}0.017 \\
\pm \\
0.00^{\mathrm{ab}}\end{array}$ & $\begin{array}{c}3.410 \\
\pm \\
0.13^{\text {ab }}\end{array}$ & $\begin{array}{c}578.88 \\
\pm \\
50.58^{\mathrm{ab}}\end{array}$ & $\begin{array}{c}76.33 \\
\pm \\
6.44^{\mathrm{a}}\end{array}$ \\
\hline $\mathbf{D}_{3}(\mathbf{A})$ & $\begin{array}{c}0.161 \\
\pm \\
0.00 \\
\end{array}$ & $\begin{array}{c}0.734 \\
\pm \\
0.36^{\mathrm{c}} \\
\end{array}$ & $\begin{array}{c}0.573 \\
\pm \\
0.04^{\mathrm{c}} \\
\end{array}$ & $\begin{array}{c}0.010 \\
\pm \\
0.00^{\mathrm{c}} \\
\end{array}$ & $\begin{array}{c}2.704 \\
\pm \\
0.09^{\mathrm{c}} \\
\end{array}$ & $\begin{array}{c}355.69 \\
\pm \\
22.57^{\mathrm{c}} \\
\end{array}$ & $\begin{array}{c}57.00 \\
\pm \\
3.46^{\mathrm{b}} \\
\end{array}$ \\
\hline $\mathbf{D}_{3}(\mathbf{B})$ & $\begin{array}{c}0.161 \\
\pm \\
0.00 \\
\end{array}$ & $\begin{array}{c}0.787 \\
\pm \\
0.10^{\mathrm{c}} \\
\end{array}$ & $\begin{array}{c}0.626 \\
\pm \\
0.10^{c} \\
\end{array}$ & $\begin{array}{c}0.011 \\
\pm \\
0.00^{\mathrm{c}} \\
\end{array}$ & $\begin{array}{c}2.802 \\
\pm \\
0.24^{\mathrm{c}} \\
\end{array}$ & $\begin{array}{c}388.82 \\
\pm \\
63.88^{\mathrm{c}} \\
\end{array}$ & $\begin{array}{c}58.00 \\
\pm \\
0.58^{b} \\
\end{array}$ \\
\hline \multicolumn{8}{|c|}{ Stocking density: } \\
\hline $\mathbf{D}_{1}$ & $\begin{array}{c}0.161 \\
\pm \\
0.00\end{array}$ & $\begin{array}{c}1.032 \\
\pm \\
0.08^{\mathrm{a}}\end{array}$ & $\begin{array}{c}0.871 \\
\pm \\
0.08^{\text {a }}\end{array}$ & $\begin{array}{c}0.0156 \\
\pm \\
0.002^{\mathrm{a}}\end{array}$ & $\begin{array}{c}3.287 \\
\pm \\
0.15^{\mathrm{a}}\end{array}$ & $\begin{array}{c}540.99 \\
\pm \\
52.70^{\mathrm{a}}\end{array}$ & $\begin{array}{c}77.67 \\
\pm \\
2.89^{\mathrm{a}}\end{array}$ \\
\hline $\mathbf{D}_{2}$ & $\begin{array}{c}0.161 \\
\pm \\
0.00 \\
\end{array}$ & $\begin{array}{c}1.079 \\
\pm \\
0.08^{\mathrm{a}} \\
\end{array}$ & $\begin{array}{c}0.918 \\
\pm \\
0.08^{\mathrm{a}} \\
\end{array}$ & $\begin{array}{c}0.0164 \\
\pm \\
0.001^{\mathrm{a}} \\
\end{array}$ & $\begin{array}{c}3.374 \\
\pm \\
0.13^{\mathrm{a}} \\
\end{array}$ & $\begin{array}{c}570.29 \\
\pm \\
48.81^{a} \\
\end{array}$ & $\begin{array}{c}75.17 \\
\pm \\
4.19^{\mathrm{a}} \\
\end{array}$ \\
\hline $\mathbf{D}_{3}$ & $\begin{array}{c}0.161 \\
\pm \\
0.00 \\
\end{array}$ & $\begin{array}{c}0.760 \\
\pm \\
0.05^{\mathrm{b}} \\
\end{array}$ & $\begin{array}{c}0.599 \\
\pm \\
0.05^{b} \\
\end{array}$ & $\begin{array}{c}0.0107 \\
\pm \\
0.00^{\mathrm{b}} \\
\end{array}$ & $\begin{array}{c}2.753 \\
\pm \\
0.12^{\mathrm{b}} \\
\end{array}$ & $\begin{array}{c}372.26 \\
\pm \\
31.19^{\mathrm{b}} \\
\end{array}$ & $\begin{array}{c}57.50 \\
\pm \\
1.59^{b} \\
\end{array}$ \\
\hline \multicolumn{8}{|c|}{ Probiotic: } \\
\hline (A) & $\begin{array}{c}0.161 \\
\pm \\
0.00 \\
\end{array}$ & $\begin{array}{c}1.005 \\
\pm \\
0.09 \\
\end{array}$ & $\begin{array}{c}0.844 \\
\pm \\
0.09 \\
\end{array}$ & $\begin{array}{c}0.015 \\
\pm \\
0.002 \\
\end{array}$ & $\begin{array}{c}3.217 \\
\pm \\
0.06\end{array}$ & $\begin{array}{c}524.36 \\
\pm \\
53.11\end{array}$ & $\begin{array}{c}67.89 \\
\pm \\
3.59^{b}\end{array}$ \\
\hline (B) & $\begin{array}{c}0.161 \\
\pm \\
0.00 \\
\end{array}$ & $\begin{array}{c}0.909 \\
\pm \\
0.06\end{array}$ & $\begin{array}{c}0.748 \\
\pm \\
0.06\end{array}$ & $\begin{array}{c}0.013 \\
\pm \\
0.001 \\
\end{array}$ & $\begin{array}{c}3.059 \\
\pm \\
0.12 \\
\end{array}$ & $\begin{array}{c}464.67 \\
\pm \\
37.63\end{array}$ & $\begin{array}{c}72.33 \\
\pm \\
4.23^{\mathrm{a}} \\
\end{array}$ \\
\hline
\end{tabular}

$\mathrm{a}, \mathrm{b}, \ldots$. Average within the same column bearing the same letters are not significantly $(\mathrm{P}>0.05)$ different otherwise they do.

Where:
$\mathrm{D}_{1} \rightarrow 50 \mathrm{pl} / \mathrm{m}^{2}$
$\mathrm{D}_{2} \rightarrow 75 \mathrm{pl} / \mathrm{m}^{2}$
$\mathrm{D}_{3} \rightarrow 100 \mathrm{pl} / \mathrm{m}^{2}$
(A) $\rightarrow$ without probiotic
(B) $\rightarrow$ with probiotic

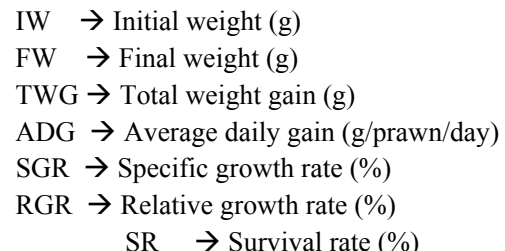


Regardless of stocking density, results in Table (3) show that probiotic tested in the present study released insignificant effects on FW; TWG; ADG; SGR and RGR, however probiotic supplementation increased significantly $(p<0.05)$ survival rate compared to the unsupplemented groups indicating that the tested probiotic increased the immune response and reduced stress effects in freshwater prawns.

Results for the insignificant effects of the tested probiotic on growth performance parameters are contradictory to that reported by Deeseenthum et al. (2007) and Keysami et al. (2012) which may be due to the fact that these authors used isolated Bacillus strains from the gut of the prawns as probiotic which influenced the growth parameters of the tested Macrobrachium rosenbergii positively.

\section{Feed conversion ratio:}

Results in Table (4) show that group $\mathrm{D}_{1} \mathrm{~A}$ showed significantly $(\mathrm{P}<0.05)$ the best feed conversion ratio (the lowest) (3.160g. diet required for each g. gain in weight) followed in a significant $(\mathrm{P}<0.05)$ increasing order by both $\mathrm{D}_{1} \mathrm{~B} ; \mathrm{D}_{2} \mathrm{~A}$, then by both $D_{3} A$ and $D_{3} B$, respectively. Differences in feed conversion ratio among $D_{1} A$ and $D_{2} B$ groups were insignificant.

Table 4: Effect of stocking density and dietary probiotic supplementation on feed intake and feed conversion ratio of $M$. rosenbergii postlarvae.

\begin{tabular}{|c|c|c|c|}
\hline & FI (g) & TWG (g) & FCR (g) \\
\hline \multicolumn{4}{|c|}{ Interaction: } \\
\hline$D_{1}(A)$ & $3.799 \pm 0.01^{\mathrm{a}}$ & $1.056 \pm 0.04^{\mathrm{a}}$ & $3.610 \pm 0.12^{c}$ \\
\hline$D_{1}(B)$ & $3.368 \pm 0.15^{a b c}$ & $0.686 \pm 0.02^{b c}$ & $4.910 \pm 0.27^{b}$ \\
\hline$D_{2}(A)$ & $3.654 \pm 0.24^{\mathrm{ab}}$ & $0.904 \pm 0.16^{\mathrm{ab}}$ & $4.042 \pm 0.48^{b}$ \\
\hline $\mathbf{D}_{2}(\mathrm{~B})$ & $3.575 \pm 0.12^{a b c}$ & $0.932 \pm 0.08^{a b}$ & $3.840 \pm 0.21 b^{c}$ \\
\hline $\mathbf{D}_{3}(\mathbf{A})$ & $3.074 \pm 0.16^{\mathrm{c}}$ & $0.573 \pm 0.04^{\mathrm{c}}$ & $5.364 \pm 0.36^{\mathrm{a}}$ \\
\hline$D_{3}(B)$ & $3.147 \pm 0.20^{\mathrm{bc}}$ & $0.626 \pm 0.10^{c}$ & $5.030 \pm 0.56^{\mathrm{a}}$ \\
\hline \multicolumn{4}{|c|}{ Stocking density: } \\
\hline $\mathbf{D}_{1}$ & $3.584 \pm 0.12^{\mathrm{a}}$ & $0.871 \pm 0.08^{a}$ & $4.115 \pm 0.32^{b}$ \\
\hline $\mathbf{D}_{2}$ & $3.615 \pm 0.12^{a}$ & $0.918 \pm 0.08^{\mathrm{a}}$ & $3.938 \pm 0.25^{b}$ \\
\hline $\mathbf{D}_{3}$ & $3.111 \pm 0.12^{b}$ & $0.599 \pm 0.05^{b}$ & $5.194 \pm 0.30^{\mathrm{a}}$ \\
\hline \multicolumn{4}{|c|}{ Probiotic: } \\
\hline (A) & $3.509 \pm 0.14$ & $0.844 \pm 0.09$ & $4.158 \pm 0.32$ \\
\hline (B) & $3.363 \pm 0.10$ & $0.748 \pm 0.06$ & $4.496 \pm 0.28$ \\
\hline
\end{tabular}

$\mathrm{a}, \mathrm{b}, \ldots$ Average within the same column bearing the same letters are not significantly $(\mathrm{P}>0.05)$ different otherwise they do.

Where:

$\mathrm{D}_{1} \rightarrow 50 \mathrm{pl} / \mathrm{m}^{2}$

$\mathrm{D}_{2} \rightarrow 75 \mathrm{pl} / \mathrm{m}^{2}$

$\mathrm{D}_{3} \rightarrow 100 \mathrm{pl} / \mathrm{m}^{2}$

(A) $\rightarrow$ without probiotic

(B) $\rightarrow$ with probiotic

As presented in Table (4) averages of feed conversion ratio for stocking densities $D_{1} ; D_{2}$ and $D_{3}$ regardless of probiotic effect were found to be $4.115 ; 3.938$ and 5.194(g. diet required for each g. gain in weight), respectively. Statistical analysis of the results indicate that $\mathrm{D}_{1}$ and $\mathrm{D}_{2}$ groups had significantly $(\mathrm{P}<0.05)$ better (lower) feed conversion ratio compared to the group with the highest stoking density $\left(\mathrm{D}_{3}\right)$. These results are in agreement with the findings of Whangchai et al. (2007); Baysa 
and Whangchai (2007); El-Sherif and Ali Mervat (2009); Langer et al. (2011) and Ibrahem (2011).

Results in Table (4) show that averages of feed conversion ratio of prawn postlarvae as affected with the probiotic tested, regardless of stocking density, were 4.158 and 4.496 (g. diet required for each g. gain in weight)for the group fed on diet unsupplemented and that supplemented with the tested probiotic, respectively and differences among the groups were insignificant.

In this connection, Keysami et al. (2012) tested the potential effects of probiotic of Bacillus subtilis isolated from juvenile $M$. rosenbergii and the suitable methods of administration (mixing, soaking, spraying and bathing) on feed conversion ratio of prawn. They reported that supplementing the prepared probiotic by the methods tested improved FCR significantly and the improvement was more pronounced in soaking method of administration.

\section{Proximate whole body chemical composition:}

Average of ash; ether extract and protein contents calculated as percent on dry matter basis of $M$. rosenbergii postlarvae as affected with stocking density and dietary probiotic are presented in Table (5). Results of this Table reveal that neither stocking density nor probiotic supplementation released significant effects on dry matter; ash; ether extract and protein contents in prawn whole bodies.

Table 5: Effect of stocking and dietary probiotic on proximate whole body chemical composition of $M$. rosenbergii postlarvae.

\begin{tabular}{|c|c|c|c|c|}
\hline & DM \% & СР \% & EE \% & ASH \% \\
\hline \multicolumn{5}{|c|}{ Interaction: } \\
\hline $\mathbf{D}_{1}(\mathrm{~A})$ & $71.28 \pm 0.38$ & $48.78 \pm 0.19$ & $4.99 \pm 0.22$ & $11.16 \pm 0.11$ \\
\hline$D_{1}(B)$ & $70.09 \pm 0.18$ & $48.38 \pm 0.18$ & $4.37 \pm 0.10$ & $11.13 \pm 0.12$ \\
\hline $\mathbf{D}_{2}(\mathbf{A})$ & $71.44 \pm 0.43$ & $48.72 \pm 0.33$ & $4.82 \pm 0.23$ & $11.10 \pm 0.14$ \\
\hline $\mathbf{D}_{2}(\mathrm{~B})$ & $70.11 \pm 0.16$ & $48.61 \pm 0.29$ & $4.90 \pm 0.28$ & $11.15 \pm 0.13$ \\
\hline $\mathbf{D}_{\mathbf{3}}(\mathbf{A})$ & $71.46 \pm 0.16$ & $49.15 \pm 0.23$ & $4.42 \pm 0.19$ & $11.29 \pm 0.06$ \\
\hline $\mathbf{D}_{3}(\mathrm{~B})$ & $70.17 \pm 0.27$ & $48.44 \pm 0.41$ & $4.41 \pm 0.19$ & $11.26 \pm 014$ \\
\hline \multicolumn{5}{|c|}{ Stocking density: } \\
\hline $\mathbf{D}_{1}$ & $70.68 \pm 0.25$ & $48.58 \pm 0.13$ & $4.67 \pm 0.14$ & $11.15 \pm 0.08$ \\
\hline $\mathbf{D}_{2}$ & $70.77 \pm 0.27$ & $48.67 \pm 0.21$ & $4.86 \pm 0.17$ & $11.13 \pm 0.09$ \\
\hline $\mathbf{D}_{3}$ & $70.81 \pm 0.22$ & $48.79 \pm 0.24$ & $4.42 \pm 0.13$ & $11.28 \pm 0.07$ \\
\hline \multicolumn{5}{|c|}{ Probiotic: } \\
\hline (A) & $71.39 \pm 0.19$ & $48.89 \pm 0.15$ & $4.47 \pm 0.13$ & $11.19 \pm 0.06$ \\
\hline (B) & $70.12 \pm 012$ & $48.48 \pm 0.17$ & $4.56 \pm 0.12$ & $11.18 \pm 0.08$ \\
\hline
\end{tabular}

$$
\begin{array}{ll}
\text { Where: } & \text { (A) } \rightarrow \text { without probiotic } \\
\mathrm{D}_{1} \rightarrow 50 \mathrm{pl} / \mathrm{m}^{2} & \text { (B) } \rightarrow \text { with probiotic } \\
\mathrm{D}_{2} \rightarrow 75 \mathrm{pl} / \mathrm{m}^{2} & \\
\mathrm{D}_{3} \rightarrow 100 \mathrm{pl} / \mathrm{m}^{2} &
\end{array}
$$

Regardless of probiotic effect, results in Table (5) reveal that stocking density had no significant effects on dry matter; crude protein; ether extract and ash contents in prawn whole bodies.

Regarding the effect of probiotic irrespective of the stocking density, results in Table (5) show that the probiotic supplementation had no significant effects on dry matter; crude protein; ether extract and ash contents in prawn whole bodies. These results are in accordance with the findings of Keysami et al. (2012) who reported that supplementing the diets of $M$. rosenbergii with probiotic containing $B$. subtilis 
isolated from juveniles $M$. rosenbergii by different methods of application had no significant effects on whole body crude protein, crude lipids and ash contents.

\section{CONCLUSION}

Based on the present results, it is recommended that the optimal stocking density of postlarvae $M$. rosenbergii lied between 50 to $75 \mathrm{animals} / \mathrm{m}^{2}$ for the maximum growth performance parameters and survival rates of prawn postlarvae reared in indoor nursery. Also the supplementation of probiotic (Ecobiol-Aqua) is recommended for its positive effect on improving the survival rate during the nursery period.

\section{REFERENCES}

A.O.A.C. (1990). "Association of Official Agricultural Chemists" Official methods of analysis. $15^{\text {th }}$ Ed. Published by the A.O.A.C., Benjamin Franklin Station, Washington. D.C.

Amabile-Cuevas, C.F.; Gardenas-Garcia, M. and Ludgar, M. (1995). Antibiotic resistance. Am. Sci., 83: 320-329.

APHA (1992). American public Health Association. Standard methods for the examination of water and wastewater. Washington, D.C., USA.

Armstrong, D.A.; Stephenson, M.J. and Knight, A.W. (1976). Acute toxicity of nitrite to larvae of giant Malaysian prawn, Macrobrachium rosenbergii, Aquacult., 9: 39-46.

Austin, B.; Stuckey, L.F.; Robertson, P.A.W.; Effendi, I. and Griffith, D.R.W. (1995). A probiotic strain of Vibrio alginolyticus effective in reducing diseases caused by Aeromonas salmonicida, Vibrio anguillarum and Vibrio ordalii. J. Fish Dis., 18: 93-96.

Baysa, R.P. and Whangchai, N. (2007). Effect of culture season and stocking density on growth and production of giant freshwater prawn (Macrobrachium rosenbergii de Man) raised in northern Thailand. Mj. Int. J. Sci. Tech. 2007, 01(02), 216-221.

Bly, J.E.; Quiniou, S.M.A.; Lawson, L.A. and Clem, L.W. (1997). Inhibition of Saprolegnia pathogenic for fish by Pseudomonas fluorescens. J. Fish Dis., 20: 35-40.

Deeseenthum, S.; Leelavatcharamas, V. and Brooks, J.D. (2007). Effect of Feeding Bacillus sp. As Probiotic Bacteria on Growth of Giant Freshwater Prawn (Macrobrachium rosenbergii de Man). Pakistan J. Bio. Sci. 10(9): 1481-1485.

Duncan, D.B. (1955). Multiple range and multiple F-test. Biometric, 11: 1-42.

El-Sherif, M. S. and Ali Mervat, A.M. (2009). Effect of Rearing Systems (Mono- and Poly-Culture) on the Performance of Freshwater prawn (M. rosenbergii) Juveniles. J. Fish. Aquatic Sci. 4(3): 117-128.

FAO (2005). Fishery Statistics. Fisheries Global Aquaculture Production Database for freshwater crustaceans (Food and Agricultural Organization). www.faostat.fao.org/faostat. /notes/unites.html

Gatesoupe, F.J. (1994). Lactic acid bacteria increase the resistance of turbot larvae, S. maximus, against pathogenic vibrio. Aquat., Living Res., 7: 277-282.

Giap, D.H.; Yi, Y. and Lin, C.K. (2005). Effect of different fertilization and feeding regimes on the production of integrated farming of rice and prawn Macrobrachium rosenbergii (De Man). Aquacult., Res., 36: 292-299. 
Graam, L.; Melchiorsen, J.; Spanggaard, B.; Huber, I. and Nielsen, T.F. (1999). Inhibition of Vibrio anguillarrum by Pseudomonas fluorescens AH2, a possible probiotic treatment of fish. Applied Environ. Microbiol., 65: 969-973.

Hsieh, C.H; Chao, N.H.; Oliviala, D.; Gomes, L.A. and Liao, I.C. (1990). Culture practices and status of the giant freshwater prawn Macrobrachium rosenbergii (de Man), in Taiwan. In: Proceedings of the $3^{\text {rd }}$ Brazilian shrimp farming congress, 15-20 October 1990. Joao Pessoa-PB. Brazil.

Huner, J.V.; Mittner, M.; Avault Jr., J.W. and Bean, R.A. (1981). Polyculture of the prawns, $M$. rosenbergii and channel catfish fingerlings, Ictalurus punctatus, in Louisiana: Two year observations. Proceedings on the Catfish Farmers of America Research Workshop, 1981, Biloxi, Mississippi, USA, pp.: 1-1.

Ibrahem, M.H.M. (2011). Using integrated system for production tomato and shrimp using nutrient film technique. M.SC in Faculty. Agric., Ain Shams University.

Jobling, M. (1983). A short review and critique of methodology used in fish growth and nutrition studies. J. Fish Biol., 23:685-703.

Karplus, I.; Hulata, G.; Wolforth, G.W. and Halevy, A. (1987). The effect of size grading juvenile Macrobrachium rosenbergii prior to stocking on their population structure and production in Polyculture. II. Dividing the population in structure into three fractions. Aquacult., 62: 85-95.

Keysami, M.A.; Mohammadpour, M. and Saad, C.R. (2012). Probiotic activity of Bacillus subtilis in juvenile freshwater prawn Macrobrachium rosenbergii (de Man) at different methods of administration to the feed. Aqua. Int., 20:499-511.

Langer, S.; Karlopia, S.K. and Bakhtiyar, Y. (2011). Effect of Different Stoking Densities on the Growth and Survival of Freshwater Prawn, Macrobrachium rosenbergii under Laboratory Conditions in Jammu. Int. J. Fish. Aqua. Sci., 1: 19-25.

Malecha, S.R.; Buck, D.H.; Baur, R.J. and Onizuka, D.R. (1981). Polyculture of the freshwater prawn, Macrobrachium rosenbergii, Chinese and common carps in ponds enriched with swinemanure. 1. Initial trials. Aquacult., 25: 101-116.

New, M. B. (1990). Freshwater prawn culture: a review. Aquaculture 88: 99-143.

New, M.B.; D'Abramo, L.R.; Valenti, W.C. and Singholka, S. (2000). Sustainability of freshwater prawn culture. Pages 429-433 in M.B. New and W.C. Valenti, editors. Freshwater Prawn Culture. The Farming of Macrobrachium rosenbergii. Blackwell Science Ltd., Oxford, London.

Phuong, N.T.; Khanh, L.V. and Wilder, M.N. (2003). Nursing of Giant Freshwater prawn (Macrobrachium rosenbergii) Postlarvae in Ponds with Different Stocking Density. Ibaraki 305-8686 Japan.

Rouse, D.B.; Stickney, R. and brick, R. (1980). Production of freshwater prawn in combination with monosex tilapia. Proceeding of the Research workshop, American Fisheries Society Fish Culture Section, 1980, Annual Convention, New Orleans, Louisiana, pp.1-1.

SAS Institute (2002). SAS. Software version 9. SAS Institute Inc. Cary North Carolina United States of America.

Saxena, V. (2003). Scientific Guidelines for farmers engaged in freshwater prawn farming in India. Aquacult. Asia Mag., 8: 17-18.

Smith, P. and Davey, S. (1993). Evidence for the competitive exclusion of Aeromonas salmonicida from fish with stress-inducible furunculosis by a fluorescent pseudomonas. J. Fish Dis., 16:521-524.

Snedecor, G.W. and Cochran, G.W. (1982). Statistical methods. $6^{\text {th }}$ edition. The Iowa State University, Press Ames, USA. 
Westerdahl, A.; Olsson, J.C.; Kjelleberg, S. and Conway, P.L. (1991). Isolation and characterization of turbot Scophtalmus maximus-associated bacteria with inhibitory effects against Vibrio angullarum. Applied Environ. Microbiol., 57: 2223-2228.

Whangchai, N.; Ungsethaphand, T.; Chitmanat, C.; Mengumphan, K. and Uraiwan, S. (2007). Performance of giant freshwater prawn (Macrobrachium rosenbergii de Man) reared in earthen ponds beneath plastic film shelters. Chiang Mai J. Sci. 34(1): 89-96.

\section{ARABIC SUMMARY}

\section{أثر معدلات التسكين والبروبايوتك على أداء النمو وكفاءة تحويل الغذاء ومعدلات الإعاثة لمرحلة ما بعد اليرقة فى جمبرى المياه العذبة أنويلة}

نبيل فهمى عبدالحكيم ـ الاسوقى السيد العزب ـ حسن يوسف علام ـ أحمد جويدة عبدالنبى جويدة

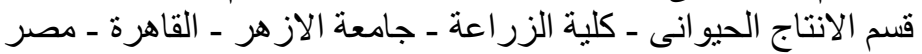

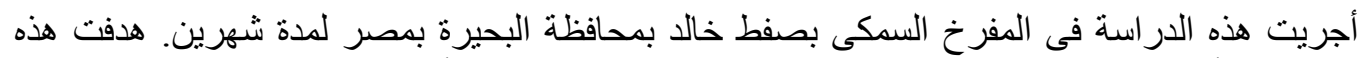

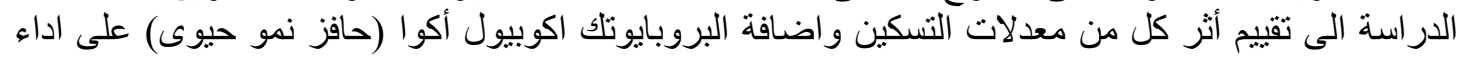

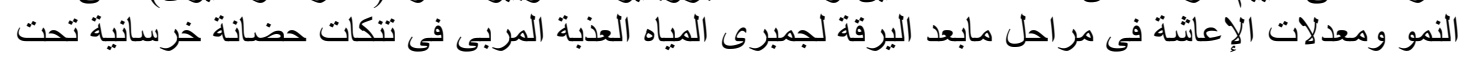

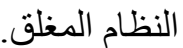

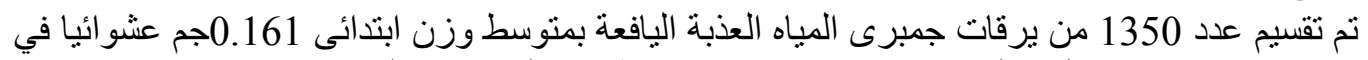

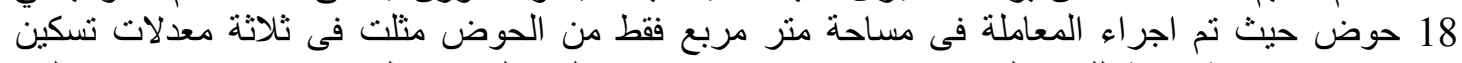

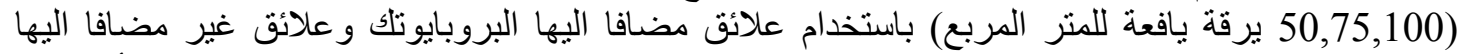

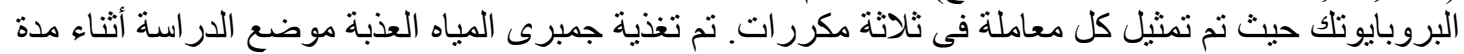

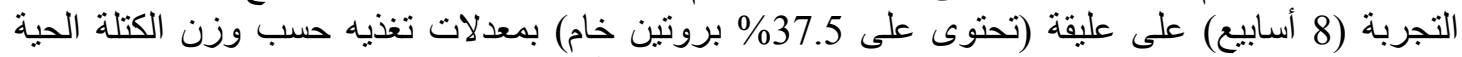

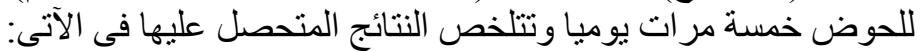

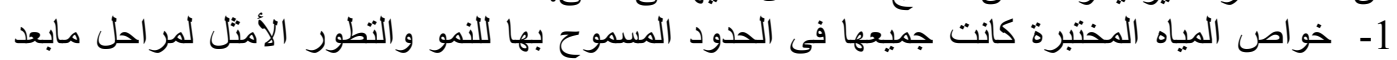
البرقة لجمبرى المياه العذبة.

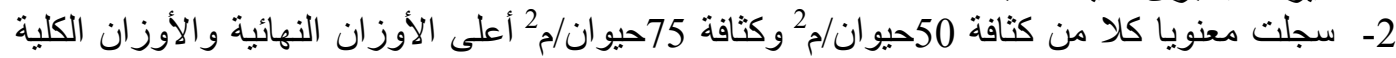

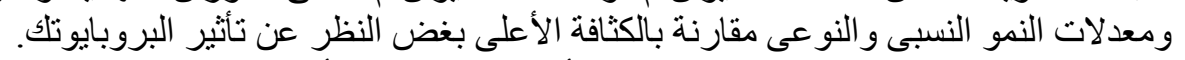

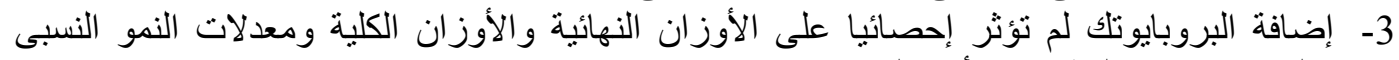

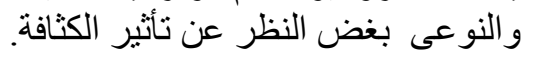

4- إضافة البروبايوتلك موضع الدر اسنة الى العلائق داخل كل معدل تسكين حسن إحصائيا معدل الإعاثة

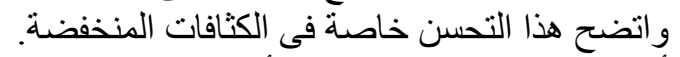

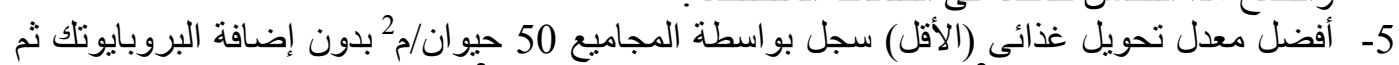

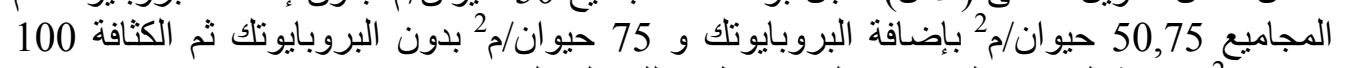

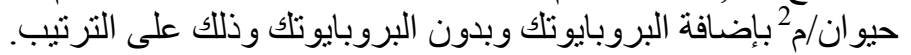

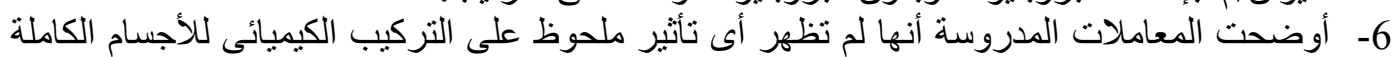
لجمبرى المياه العذبة.

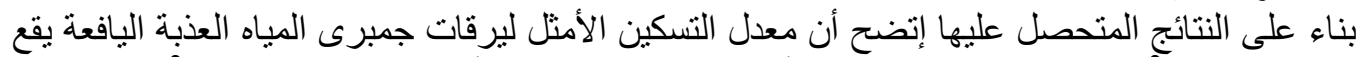

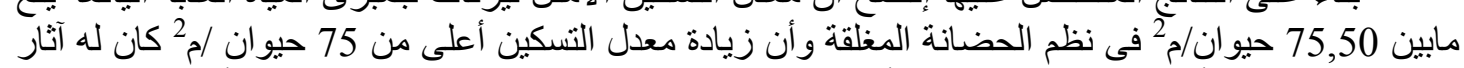

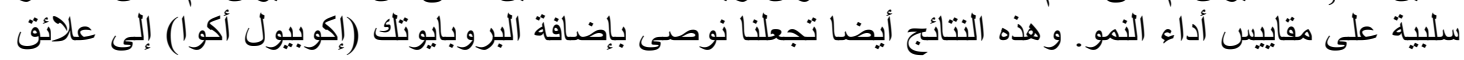

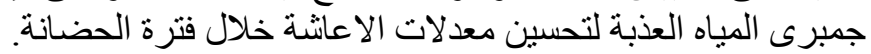

